\title{
How John Howard Positioned Himself as Indigenous Australia's Champion
}

Tim Rowse

The Australian National University

Abstract: As prime minister from 1996 to 2007, John Howard found it necessary to try to project himself as sympathetic to Indigenous Australians, but this was not easy for the leader of a government committed to the conspicuous reversal of policy wins by Indigenous Australians under the Hawke and Keating governments (1983-96). Howard's summary term, in Lazarus Rising, for the policy paradigm from which he wished his government to break was 'separate development'. In this article, I argue against taking Howard at his word. Howard pragmatically reconciled his government to much that could be called 'separate development': amending (rather than repealing) the Commonwealth Native Title Act 1993, retaining the Aboriginal and Torres Strait Islander Commission (ATSIC) (after cutting its budget), building up Keating's Indigenous Land Fund, revising (rather than extinguishing) the distinct statutory regulation of Indigenous corporations and initiating the Indigenous Protected Areas program. At the same time as he made these concessions to 'separate development', Howard sought and cultivated allies among an increasingly differentiated cast of Indigenous leaders - not least, those who had become disenchanted with ATSIC and those whose power base was distinct from it. Central to Howard's appeal to these men and women was his sincere 'compassion' for Indigenous suffering and his commitment to ameliorating their 'disadvantage- - what he called 'practical reconciliation'. By March 2004, with the Opposition abandoning ATSIC, and with a growing critical commentary on Indigenous affairs from Indigenous leaders themselves, it was possible for Howard to act more boldly against the norms of 'separate development'. As well as abolishing ATSIC in 2004-05, he authorised the Northern Territory Emergency Response in June 2007, with sufficient Indigenous support that opinion (both Indigenous and non-Indigenous) was now divided as to whether he had shown himself to be Indigenous Australia's champion. 
According to his personal and political autobiography Lazarus Rising (published in 2010), it took John Howard (Prime Minister of Australia from March 1996 to November 2007) until June 2007 to actualise his preferred approach to Indigenous affairs. Howard recalled this as 'a paradigm change. It was as if the dam had finally burst and much of the approach which had held sway for a generation or more was swept away.' Howard is referring to his government's taking over of Indigenous affairs in the Northern Territory-known as the Northern Territory Emergency Response (NTER) - a program whose controversial elements included un-negotiated amendments to the Aboriginal Land Rights (Northern Territory) Act 1976 and restrictions on welfare recipients' choices about spending money. In what ways was the Northern Territory intervention 'paradigmatic' of a new approach, and why was it not until the eleventh hour of Howard's prime ministership that Howard achieved this break from the past?

In answering this question, I depart from previous treatments of Howard's Indigenous policies that emphasise his ideological consistency; his dogged emphasis on national unity; his insistence that equality means sameness; and his attempts to discredit the idea that Indigenous Australians, as a colonised people, are entitled to make distinct, rights-based claims on the nation in the name of social justice. ${ }^{2}$ While I agree with such commentaries' descriptions of what Howard said and did, I distinguish my approach by accepting promptings that I find in Lazarus Rising. There, Howard presents himself as uneasy when handling Indigenous policy - a point not inconsistent with three political scientists' views that Indigenous affairs was less important to Howard than economic policy, including industrial relations policy. Paul Strangio, Paul 't Hart and James Walter argue that Howard's 'distaste for climate activists, welfare advocates

1 John Howard, Lazarus Rising: A Personal and Political Autobiography (Sydney: HarperCollins 2010), 283.

2 Before the 2007 Northern Territory intervention triggered its own large commentary literature, there was a corpus of critical analysis of Howard's Indigenous policy record. A themed double issue of the Journal of Australian Indigenous Issues 9 (2007) included Sarah Maddison, 'A Decade of Lost Opportunities: The Howard Government and Indigenous Policy', 2-26; Dominic O'Sullivan, 'John Howard and the Politics of Reconciliation', 27-42; Will Sanders, 'Indigenous Affairs and the Howard Decade: Administrative Reform and Practical Reconciliation Or Defying Colonization?', 43-54; Andrew Gunstone, 'The Impact of the Howard Government upon the 1991-2000 Formal Australian Reconciliation Process', 55-69; and Jane Robbins, 'Policy, Populism and Public Opinion: Indigenous Issues in the Howard Decade', 71-91. As well, I note Jane Robbins, 'The Howard Government and Indigenous Rights: An Imposed National Unity?', Australian Journal of Political Science 42 (2007), 315-28, doi.org/10.1080/10361140701320042; Will Sanders, 'Never Even Adequate: Reconciliation and Indigenous Affairs', in Howard'second and Third Governments, ed. Chris Aulich and Roger Wettenhall (Sydney: UNSW Press 2005), 152-72. 
and the "Aboriginal industry" hindered open-minded engagement with their claims for most of his term. ${ }^{3}$ Howard recalled in 2010: 'I did not have a politically correct approach to Aboriginal issues. I did not believe in separate development for the Indigenous people of Australia. ${ }^{4}$ Lazarus Rising conveys Howard's uncomfortable awareness of the legacy of his predecessor as prime minister, Paul Keating. Howard needed to find his own terms in which to present himself as a champion of Indigenous Australia, though, as I will argue, not believing in 'separate development' did not mean that he banished from government some practices that can well be described as 'separate development'.

In characterising Howard's ideological difficulties, I take full measure of a change in Australian political culture wrought by successive governments' commitment to 'reconciliation' since 1990: the rise of Indigenous Australians' moral status as the nation's aggrieved interlocutor. ${ }^{5}$ 'Reconciliation' has intensified the necessity for any leader of Australia to show that Indigenous Australians (or at least many of them) believe in his/her commitment to social justice. The High Court's Mabo judgment in 1992 gave Keating an opportunity to achieve substantial reforms (native title legislation) after negotiating with Indigenous leaders who were widely respected, including some who held senior office in a Commonwealth statutory authority, the Aboriginal and Torres Strait Islander Commission (ATSIC).

After illustrating Howard's sensitivity to the challenge that Indigenous affairs offered, I will argue that, notwithstanding his evident wish to distinguish himself rhetorically from Hawke and Keating, his policies until 2004 (not least his qualified embrace of the Native Title Act 1993) were in substantial continuity with the Australian Labor Party's (ALP). That is, I will argue that Howard found it necessary to accept much that could be called 'separate development' (a term that lacks clear definition in his writing and speaking). I will then suggest that what was novel about the 'paradigm shift' was the evident endorsement of many Indigenous leaders.

3 Paul Strangio, Paul 't Hart and James Walter, The Pivot of Power: Australian Prime Ministers and Political Leadership 1949-2016 (Carlton: The Miegunyah Press, 2017), 224.

4 Howard, Lazarus, 271. On page 282 he refers to 'separate development' as 'almost the dominant thought stream about Indigenous Affairs in Australia'.

5 See Tim Rowse and Anna Pertierra, 'From White Nation to White Caution: Non-Indigenous Reflections on Indigenous Difference', Journal of Australian Studies 43, (2019): 283-98, doi.org/ 10.1080/14443058.2019.1640769; Tim Rowse, 'Reconciliation as Public Culture: Taking Cultural Studies Beyond Ghassan Hage's "White Nationalist”', Cultural Studies Review 25 (2019): 104-08, doi.org/10.5130/csr.v25i2.6884. 


\section{Indigenous Affairs as a Challenge to National Leaders}

How Australia's leaders position themselves on Indigenous affairs has become an important criterion of the quality of their leadership. When Prime Minister William McMahon (1971-72) failed to satisfy the increasingly popular demand for recognition of Aboriginal land rights on Australia Day in 1972, Aboriginal activists responded by forming the Aboriginal Tent Embassy. Opposition leader Gough Whitlam was able to visit the Tent Embassy with the assurance that the ALP had 'land rights' in its platform. The contrast between a defensive McMahon and a challenger perceived as just and generous helped to define the electoral contest of 1972, and the Whitlam government (after getting expert advice from Justice A. E. Woodward in 1973 and 1974) introduced a Bill for Northern Territory land rights in 1975. The Bill was modified by the succeeding Fraser (Liberal-National Country Party) government in 1976, and the resulting law confirmed that legislated land rights in the Northern Territory had become bipartisan policy.

The lesson of this transition from McMahon to Whitlam to Fraser was that a prime minister looked better if he could be seen to uphold some conception of Indigenous Australians' rights. One important task for Australian leaders since then has been to form a sympathetic public relationship with a demanding Indigenous constituency. Articulate and morally urgent, the Indigenous Australian demand for a fair go submits each leader to a test that some politicians fail. In Lazarus Rising, Howard presents a vignette of an 'unnerving performance' by Alexander DownerLiberal Party leader from May 1994 to January 1995. When speaking to a Liberal Party meeting in Western Australia and then to Aboriginal people in the Northern Territory, Downer had seemed inconsistent on the issue of native title. According to Howard, his floundering 'precipitated a big fall of 17 per cent in his approval rating'. ${ }^{6}$ Howard came to power knowing that it would be better for him to be able to present himself not only as consistent but also as committed to socially just dealings with Indigenous Australians. He did not find this easy.

6 Howard, Lazarus, 204. 
Paul Keating had won admiration for his Redfern Park speech in December 1992, in which Keating told a national story that resonated with revisionist scholarship and with the critical history recited in June 1992 by the High Court of Australia in the Mabo judgment. Keating's speech challenged non-Indigenous Australians to empathise with Indigenous suffering; he committed the nation to the repair of an historically damaged relationship between Indigenous and non-Indigenous Australians. Then, after negotiations with state and territory governments and with Indigenous leaders (including those elected to lead ATSIC), Keating legislated the Native Title Act and the Indigenous Land Fund Act 1995, presenting them as major reparative steps. No prime minister since Whitlam had enjoyed such an opportunity to present himself as the author of a revised settler colonial compact. The Coalition parties, under John Hewson, opposed the Commonwealth's legislative recognition of native title in 1993. They had not seen the Mabo judgment as a provocation to revise their account of Australian ideals, and they had wanted each state and territory merely to validate titles to non-Indigenous people, with the Commonwealth paying compensation to any native title holders who could prove, in the courts, that a government's administration of titles had extinguished a ('native title') property right. Though Keating's approach to native title was not universally supported, he gained stature from the contrast between seeing native title as a fixable problem for non-Indigenous property interests (the Opposition approach) and seeing native title as a means to repair the Indigenous-non-Indigenous relationship through national legislation.

To present a more sympathetic Coalition posture on native title was an ideological necessity for the non-Labor parties after 1993, lest Labor continue to distinguish itselfas Indigenous Australia's only champion. It did not escape Howard's notice that, in the years leading up to the Coalition's electoral victory in March 1996, Keating's handling of native title had won credit for the Labor Party. In a 1995 speech, Howard protested that 'no side of politics in Australia has a mortgage on compassion'. ' Later, in a 1998 speech, Howard recalled Keating 'talking about how the native title bill was going to nourish the Labor Party for two generations' ${ }^{8}$ In Lazarus Rising, Howard recalls being offended by the ideological bond-as he saw it - that had formed between the press, the Aboriginal leadership and the Keating Cabinet in the period 1992-96. ${ }^{9}$

7 Howard, Commonwealth Parliamentary Debates, House of Representatives (henceforth CPD HoR), 2 March 1995, 1410.

8 Howard, CPD HoR, 3 July 1998, 6050.

9 Howard, Lazarus, 189-90, 273, 587-88. 


\section{Howard Differentiates Himself}

As prime minister, Howard sought to undermine the assumption that Labor's policies had come to define social justice for Indigenous Australia - that is, Labor MPs' evident belief that they 'hold some kind of monopoly of concern about the Aboriginal people of Australia'. ${ }^{10}$ To break this apparent monopoly, Howard had to give his own meaning to 'reconciliation', which he described as 'an unstoppable force'. ${ }^{11}$ In 1991, the Coalition parties had voted for the Bill that established the Council for Aboriginal Reconciliation; in government, Howard sought to control the meaning of that 'unstoppable' idea. ${ }^{12}$ In May 1997, Howard aligned his approach to 'reconciliation' with what he called 'the spirit of the 1967 referendum': 'If the 1967 referendum spoke of anything it spoke of a need to remedy in a practical way the disadvantage of the Aboriginal and Torres Strait Islander people. ${ }^{\prime 3}$ I have counted 16 uses of the word 'practical' in 10 parliamentary statements about Indigenous affairs that Howard made from 1996 to 1999. In Howard's view, while there was debate on some Indigenous policy issues, there was wide agreement that to relieve disadvantage reconciliation must include policies that were 'practical'; this consensus meant that 'nobody has any kind of moral monopoly of concern about Indigenous people'. ${ }^{14}$

The alternative to being practical, in Howard's terms, was to be guilt ridden and morally vain. In 1989 Howard had characterised Prime Minister Bob Hawke as 'guilt ridden'. ${ }^{15}$ In 1995 he vowed: 'I am not going to be party to the guilt industry. ${ }^{16}$ In 1996 , speaking on a motion about 'racial tolerance', he complained of a climate of 'excessive political correctness in political debate in this country'. ${ }^{17}$ Denying in 1998 that Coalition policies were stuck in a racist posture, he rejected what he called Labor's

10 Howard, CPD HoR, 3 July 1998, 6050.

11 John Howard, Howard: The Art of Persuasion Selected Speeches 1995-2016, ed. David FurseRoberts (Cleveland [Qld]: Jeparit Press 2018), 252.

12 Angela Pratt has exhaustively documented the many references to 'reconciliation' in the Australian parliament and the contest over whether 'Indigenous rights' were central to, or a distraction from, reconciliation. Angela Pratt, Practising Reconciliation? The Politics of Reconciliation in the Australian Parliament, 1991-2000 (Canberra: Parliament of Australia Department of Parliamentary Services 2005).

13 Howard, CPD HoR, 27 May 1997, 4111.

14 Howard, CPD HoR, 27 May 1997, 4112.

15 Howard, CPD HoR, 11 April 1989, 1330.

16 Howard, CPD HoR, 2 March 1995, 1412.

17 Howard, CPD HoR, 30 October 1996, 6158. 
'phoney claims of racism'. ${ }^{18}$ In Lazarus Rising, he scorns Labor's criticism of himself as 'McCarthyist smear tactics'. ${ }^{19}$ He was deeply offended by the 'vitriol' of an Age cartoon depicting himself and Peter Reith mounted on horses and shooting Aboriginal people. He recalls his pleasure at Robert Tickner losing his seat in 1996, as Tickner had epitomised 'the politically correct left of the Labor Party'. ${ }^{20}$ Howard made no secret of his dislike of 'the abjectly apologetic language so often used by the Labor Party and others' ${ }^{21}$ It seems to have troubled Howard that Aboriginal leaders and many other Australians expected his and his government's 'abjection'. His refusal to apologise to the Stolen Generations, after the tabling of the Bringing Them Home report in April 1997, showed his distaste for the 'abject' position. For that refusal, he was punished by the open disdain of Aboriginal leaders and many in the press, as the stories of the Stolen Generations attracted much public sympathy. Televised images of his May 1997 confrontation with a largely Indigenous audience 'played strongly to the view that I was at permanent loggerheads with Indigenous Australians', he recalls. ${ }^{22}$ Patrick Dodson's refusal of reappointment to the chair of the Council for Aboriginal Reconciliation was a public rebuff. In October 1997, Noel Pearson called Liberals 'racist scum'. ${ }^{23}$ It seemed to Howard that, from 1996 until after the 2004 election, 'the bulk of Australia's Aboriginal leadership was unwilling to accept our legitimacy'. ${ }^{24}$

In its first budget (for 1996-97), the Howard government cut the appropriation to ATSIC. The Coalition parties in opposition had very often characterised Indigenous affairs expenditure as wasteful and ill-directed. On 2 March 1995, Howard told the House:

There is also within the Australian community a growing impatience with what seems to it to be the expenditure of hundreds of millions of dollars, with precious little advancement and, in some cases, actual regression. ${ }^{25}$

18 Howard, CPD HoR, 3 July 1998, 6050.

19 Howard, Lazarus, 259.

20 Howard, Lazarus, 225.

21 Howard, Lazarus, 276.

22 Howard, Lazarus, 277.

23 Howard, Lazarus, 283.

24 Howard, Lazarus, 277-78.

25 Howard, CPD HoR, 2 March 1995, 1411. 
The cut to ATSIC was part of a total reduction in the real value of Commonwealth funds identified as expenditure on Indigenous Australians, from $\$ 2.45$ billion in the 1995-96 (Keating) budget to $\$ 2.35$ billion in the 1996-97 (Howard) budget-a fall (in real terms) of about 4 per cent. In making such cuts, the Howard government repeated-but in milder form-what the Fraser government had done: the 1976-77 Commonwealth budget had reduced the real value of Commonwealth funds devoted to Indigenous programs by 22 per cent. By limiting itself to a 4 per cent cut in 1997, the Howard government can be interpreted as accepting that the Commonwealth should annually spend on Indigenous programs an amount equal to about one-third of 1 per cent of GDP. This level of spending was achieved under the Keating government in 1992-93 and remained, with small fluctuations, throughout the Howard government. ${ }^{26}$

Notwithstanding that ATSIC's cuts seemed to confirm that the Coalition would undermine much that the Hawke and Keating governments had achieved, there are more continuities than differences between what the Labor and Coalition governments did over the period 1989-2004. These continuities further underline Howard's ideological problem: how to project a distinctly conservative (non-'abject') approach to social justice in Indigenous affairs? In 1989 he had opposed legislating ATSIC, warning that to take 'the principle of self-determination for Aborigines to the point of creating completely separate representative structures ... is a very bad step for the long term unity of this country'. ${ }^{27}$ Although Howard tried to subject ATSIC to greater accountability to the relevant minister, the Coalition did not abolish ATSIC until after the Labor Party, in Opposition, had announced in March 2004 that it had lost faith in ATSIC. Other continuities between Labor and the Coalition in Indigenous affairs include the Native Title Act and the regulation of the Indigenous sector. These continuities could be explained by saying that there is a limit to how many reforms a new government can tackle at once (the basis of much 'path dependency' in public policy). Eventually, one might argue, Howard got what he wanted. However, I wish to explore the possibility that, in Australia, Indigenous affairs policy is more bipartisan than Howard's rhetoric (and critics of that rhetoric) have noticed.

26 The financial data in this paragraph are drawn from John Gardiner-Garden and Malcolm Park, 'Commonwealth Indigenous-Specific Expenditure 1968-2008', Parliamentary Library Research Paper, 26 September 2008, no. 10, 2008-09, Table 1.

27 Howard, CPD HoR, 11 April 1989, 1332. 
The problem for Howard was to find an Indigenous affairs ideology that addressed conservative disquiet about the gains made by Indigenous Australians under Keating while reaching out to Indigenous Australians as their champion - all the while maintaining a high degree of legislative and institutional continuity in what the government actually did.

\section{Amending and Accepting the Native Title Act, 1996-98}

In 1993 Howard and other Liberals and the National Party had opposed Keating's Native Title Bill in its entirety. The Coalition had responded defensively to the High Court's recognition of native title. The challenge that the Coalition sought to meet was that some issued titles were possibly invalid: where there was any doubt, the state and territory and Australian governments should combine to pass validating legislation, with compensation in cases where validation extinguished a proven native title right. Each state and territory would be free to establish its own processes for judging assertions of native title to lands not yet under any other title. Howard did not speak in the 1993 debate over the Bill, but his leader, John Hewson, denounced the Native Title Bill as:

Bad legislation because it goes way beyond what the High Court decided in the Mabo case. It is bad because it creates enormous complexity, delay, uncertainty, and division in Australian society. It is bad because it assumes a mistaken view of the root cause of Aboriginal and Islander disadvantage. It is bad because, without good reason, it constrains future opportunities for national development to the detriment of all Australians, and it creates future financial liabilities, the scale of which no-one can predict. ${ }^{28}$

The flaw in the Opposition's stance was that no one knew how much the Commonwealth would have to compensate those who could prove that the proposed 'blanket' validation law extinguished native title. In government, the Coalition was prepared to admit this problem, as Howard explained in May 1997:

The government has not opted for the blanket extinguishment route because, in our view, blanket extinguishment would involve unnecessarily expensive and protracted litigation. It could be

28 John Hewson, CPD HoR, 23 November 1993, 3406. 
exposed to constitutional challenge and it would in symbolic terms also be seen as a far greater affront to what the indigenous people of Australia had achieved in the native title area than other approaches. ${ }^{29}$

Howard's acknowledgement that 'native title' was an issue with a 'symbolic' aspect implicitly conceded much public sympathy for native title. The Howard government knew that any change perceived as reducing native title holders' rights would face hostile scrutiny in the Senate, where the Coalition's 37 seats after the 1996 elections did not amount to a majority.

Howard committed to amending the Native Title Act in ways that would conciliate miners and pastoralists. On 17 June 1996, the government presented an amending Bill and, in October 1996, an exposure draft. The amendments would give the minister more discretion over how native title holders could negotiate mineral exploration proposals, and would increase the rights bestowed by a pastoral lease, including allowing perpetual rights to be conferred in such a lease. Not all of Howard's proposed amendments were in the miners' and pastoralists' favour; the enlarged responsibilities of Aboriginal and Torres Strait Islander representative bodies, and the stricter test for registering an interest in asserting native title, arguably contributed to empowering bodies acting for native title holders, and some amendments were designed to make it more attractive to negotiate land use agreements, which were helpful to Indigenous interests who were well organised and well advised.

Before the amendments could be legislated, another decision by the High Court stimulated the Howard government to revise the amending Bill. Ruling on The Wik Peoples v. Queensland in December 1996, a 4:3 majority of judges confirmed that native title might coexist with a pastoral lease over the same land, conferring distinct rights on native title holders and on leaseholders. If a pastoral lease extinguished only those native title rights with which the specific terms of the pastoral lease conflicted, some native title rights were likely to continue: a pastoral lease was not necessarily a right of exclusive possession. These residual native title rights-however trivial — could be the basis of a native title holder's procedural right, such as the right to negotiate with a miner who wished to explore for minerals on a pastoral lease. Because pastoral leases did not give the pastoralist a right to negotiate with miners, the Wik judgment created the possibility that native title holders and pastoral lessees, facing

29 Howard, CPD HoR, 27 May 1997, 4113, emphasis added. 
a mining company seeking exploration rights, would be negotiating from different positions; the pastoralists would find themselves with only a right to compensation for land disturbance, while those holding residual native title rights could conceivably negotiate to share in the fruits of the miner's discovery. As well, the Wik ruling said that, when a pastoral lease expires, the rights do not necessarily revert in full to the Crown. This meant that a pastoralist wishing to renew a lease might have to make an agreement not only with the Crown but also with anyone identified as holding a native title interest. Finally, the $W i k$ judgment produced no clear answer to the question of how the Commonwealth Racial Discrimination Act 1975 should apply to surviving native title rights-reopening the question of how to validate pastoral leasehold. The Wik judgment created enough uncertainties to warrant legislation giving clear definition to the rights of each party. ${ }^{30}$ The political question was whether native title rights should be further circumscribed by such clarification.

Responding to Wik, the Howard government revised its amending Bill in April and May 1997. In the face of criticism by the National Indigenous Working Group (NIWG) that the amendments would increase pastoralists' rights at the cost of reducing native title rights, Howard agreed that the amendments 'deliver great certainty to the pastoralists and the miners of Australia'. ${ }^{31}$ However, 'it is a question of achieving a fair balance'. Howard told the Reconciliation Convention on 26 May 1997 that his amendments would respect both:

The principles of Native Title, as laid down in the Mabo decision, and the very legitimate interests of pastoralists and others in securing certainty in carrying on and planning their activities. ${ }^{32}$

The NIWG, backed by Australians for Native Title and Reconciliation, found the non-government senators sympathetic. The parliament debated the Bill three times between September 1997 and June 1998, before passing most amendments. In this way, Howard found a way to work with native title as an established feature of policy. By reshaping a Commonwealth law, binding states and territories, the Coalition felt

30 Frank Brennan, The Wik Debate: Its Impact on Aborigines, Pastoralists and Miners (Sydney: UNSW Press, 1998), 48-49.

31 For a summary of criticism of Howard's amendments see Sarah Pritchard, 'Native Title from the Perspective of International Standards', The Australian Yearbook of International Law 18 (1997): 133, doi.org/10.22145/aybil.18.4; Howard, CPD HoR, 27 May 1997, 4113.

32 Howard, 'Transcript of the Prime Minister the Hon John Howard MP: Opening Address to the Australian Reconciliation Convention Melbourne', 1997, 6, accessed 17 January 2020, pmtranscripts. pmc.gov.au/sites/default/files/original/00010361.pdf. 
they now 'owned' an Act that, in 1993, they had voted against. Further, by realigning the Coalition so that Liberals and Nationals could accept the Commonwealth's authority over states' and territories' handling of native title, Howard opened ideological space for the Coalition to accept the native title regime and to adapt it.

Another part of Keating's native title legacy was the Indigenous Land Fund, which the Keating government had legislated in 1995 to meet some of the territorial needs of Indigenous Australians whose native title had been totally extinguished. As required by Keating's legislation-which the Howard government did not seek to amend-Howard's budgets paid increasing amounts into the fund every year of his prime ministership, building its power to purchase assets for Indigenous Australians. ${ }^{33}$ However, we should note that Patrick Sullivan has argued that, during the Howard years, the goal of land acquisition - the original and singular mission of the Indigenous Land Corporation (the spender of revenues generated by the fund) - was compromised by other objectives designed to increase the employment and income of Indigenous Australians. ${ }^{34}$ One more example of the Howard government's adaptation to the reality of a Commonwealth native title policy is that, in 1997, the Commonwealth initiated the Indigenous Protected Areas (IPA) program, in which native title holders sign nature conservation agreements with Commonwealth and state/territory agencies and receive public funding for land management programs that employ Indigenous Australians. The IPAs enable Australia to meet its obligations under global conservation agreements. ${ }^{35}$

Let us pause to examine the terms in which Howard justified his version of the Native Title Act. Rejecting the amendments to his Bill that were imposed by the Senate in December 1997, Howard represented his government as being above all competing interests:

We have not surrendered to all the blandishments of the indigenous community; we have not surrendered to the blandishments of the farmers; and we have not surrendered to the blandishments of the mining industry. We have tried to provide a framework

33 Section 193 of the Land Fund and Indigenous Land Corporation (ATSIC Amendment) Act 1995 stipulated a formula for calculating what the Commonwealth should credit to the Land Fund each year. 34 Patrick Sullivan, 'Policy Change and the Indigenous Land Corporation', AIATSIS Research Discussion Paper, no. 25, July 2009, 11-12.

35 Jon Altman and Francis Markham, 'Burgeoning Indigenous Land Ownership: Diverse Values and Strategic Potentialities', in Native Title from Mabo to Akiba, ed. Sean Brennan, Megan Davis, Brendan Edgeworth and Leon Terrill (Annandale: The Federation Press 2015), 137-38. 
and a pathway which will guarantee certainty, which will deliver workability, which strikes a fair and decent balance in an extraordinarily difficult situation. ${ }^{36}$

As well as claiming the Bill to be politically neutral-displeasing all interests ('blandishments') to some degree-Howard claimed that the Act would now adhere to a 'sacred principle' of equality under the law. That is, in the eyes of the Howard government, pastoralists and native title holders should be equal in their rights to negotiate with a third party (such as a mining company). It would be:

Wrong in principle that there should be a right to negotiate over pastoral leaseholdings subject to mining applications in the hands of indigenous claimants, yet that right is not available to farmers and pastoralists. We do not believe that that right should be available to one group and not available to others. ${ }^{37}$

Let us note a significant difference between these two justifications: the claim to be strong (finding the neutral path between clamorous sectional interests) is not the same as the claim to be honouring a 'sacred principle'.

Whether boasting of his strong neutrality or pointing to his respect for 'equality', Howard was not able to present himself as being Indigenous Australia's champion. Far from it. He had to admit that, for the greater good (as he saw it), he was winding back Indigenous gains. On the 30th anniversary of the 1967 referendum (27 May 1997), Howard conceded that his proposed amendments to the Native Title Act were intended to reduce the rights of native title holders whose ancestral country was under pastoral lease. He defended this reduction of rights as a restoration of equality under the rule of law because 'the pendulum had swung too far' towards Indigenous rights. ${ }^{38}$

\footnotetext{
36 Howard, CPD HoR, 6 December 1997, 12337.

37 Howard, CPD HoR, 9 April 1998, 2959.

38 Howard, CPD HoR, 27 May 1997, 4113. Critical assessment of the Native Title Act from an Indigenous point of view must seek to distinguish problems attributable to the original Act from problems added by the 1998 amendments on Indigenous interests. This is too big a topic to be squeezed into this paper. However, let us note that David Ritter, after working for a Native Title Representative Body subsequent to Howard's amendments, argued that the amendments, the Federal Court's interpretations in particular cases and the perspective of the National Native Title Tribunal in arbitration combined to establish a native title system in which miners and pastoralists felt secure in clearly defined rights, making them more likely to negotiate with native title interests. 'The cumulative consequence was a clear trend upwards in the rate of resolving native title claims by consent.' See David Ritter, Contesting Native Title (Crows Nest: Allen and Unwin, 2009), 137.
} 


\section{Politicising Compassion}

Openly to reduce Indigenous rights was to court another possible ideological option: appealing to sections of the Australian public that were expressly hostile to the 'privilege' of Indigenous Australians. Accusations of Indigenous 'privilege' had recently been emboldened by the rise of One Nation, whose leader Pauline Hanson entered parliament as the independent member for Oxley in March 1996. Her claim that Indigenous people were privileged seemed to appeal to some voters. Thus, it would have been a tempting tactic for the Coalition to justify the winding back of native title rights as the cancelling of Indigenous privilege. Indeed, it would have been possible to fight an election on whether 'native title' was a privilege (to be curbed) or a right (to be upheld). The possibility of an electoral contest arose because, under Section 57 of the Australian constitution, any government whose legislation is thwarted twice in the Senate is entitled to dissolve both Houses (a 'double dissolution') and to call an election in which all (not half) the senators must stand. An election on Howard's amendments to the Native Title Act could have enabled the electorate to say whether the government was right to curtail Indigenous privileges or wrong to reduce Indigenous rights. Howard's tactics towards the Senate, between the Senate's first (December 1997) and second (April 1998) amending debates, included allowing the prospect of double dissolution to enter into the minds of all senators. According to a chronicler of the period, on 6 February Howard released a specially produced broadcast to rural television and radio stations in which he argued that the Senate's amendments to his Bill were unacceptable because they unreasonably gave 'superior rights' to native title claimants over pastoralists. On 16 June, National Party leader Tim Fischer warned that the government would take the Native Title Bill 'to the people'. ${ }^{39}$

Speculation about an 'election on race' (as pundits were then calling it) aroused fear on both sides of the native title debate-not only that some MPs might lose their seats but also that One Nation, seen by many as an openly racist party, might increase its parliamentary strength at the Coalition's expense. According to Ian Ward, senior Liberals were talking to Indigenous leaders about how to avoid an election in which native title would be a central question. When the government finally won the

39 Ian Ward, 'Political Chronicles: Commonwealth of Australia January to June 1998', Australian Journal of Politics and History 44 (1998): 568, doi.org/10.1111/1467-8497.00037. 
vote of a key senator, Brian Harradine, on 21 June, it may well have been because Harradine was aware of opinion polls predicting that One Nation would increase its Senate representation in such an election. ${ }^{40}$

Howard was sensitive to the observation that, in winding back native title rights, he was pursuing a One Nation agenda and thus legitimising antiIndigenous feeling. On 3 June 1998, he told the ABC's Fran Kelly that in some of Hanson's criticisms of Indigenous rights she was 'fanning racist sentiment'. ${ }^{41}$ In Lazarus Rising, Howard continued to distinguish himself from Hanson: while in attacking 'multiculturalism, ATSIC and separatist policies for black and white Australians' he and Hanson were in tune with 'community sentiment', they differed on whether Indigenous Australians 'were the most disadvantaged group in our midst'. ${ }^{42}$ Howard says that what distinguished him from One Nation was that he always presented Aboriginal people as the deserving disadvantaged.

Certainly, this was his theme. He asserted 'compassion' for Indigenous Australians in a 1995 speech. ${ }^{43}$ In 1996 he named Aborigines and Torres Strait Islanders as 'the most profoundly disadvantaged within our midst'. ${ }^{44}$ In May 1997 he rebuked those who denied the reality of Aboriginal disadvantage:

Anybody who argues that Aboriginal and Torres Strait Islander people are not as a group more profoundly disadvantaged than other sections of the Australian community are flying in the face of reality. People who argue that are substituting fiction for fact. They are substituting selective anecdotes for irrefutable statistical proof and they are also ignoring the realities that are around us to see..$^{45}$

Howard developed the theme of compassion for the disadvantaged as his defining approach to Indigenous policy.

40 Ward, 'Political Chronicles', 568-69.

41 'John Howard Calls Pauline Hanson "Deranged", AustralianPolitics.com, accessed 17 January

2020, australianpolitics.com/1998/06/03/howard-calls-hanson-deranged.html.

42 Howard, Lazarus, 256.

43 Howard, CPD HoR, 2 March 1995, 1411-12.

44 Howard, CPD HoR, 30 October 1996, 6158.

45 Howard, CPD HoR, 27 May 1997, 4111. 


\section{Howard and Indigenous Corporations}

The theme of 'disadvantage' is subtly present in Howard's approach to the regulation of the Indigenous sector. It has been a continuing expectation by both Coalition and Labor governments since the 1970s that Indigenous Australians will become skilled functionaries in what has become known as the Indigenous sector. ${ }^{46}$ Under policies described as 'self-determination' and 'self-management', Australian governments had encouraged Indigenous Australians to form corporations in order to hold title to Indigenous property, advocate their needs, deliver services and manage employment programs (particularly the Community Development Employment Projects, or CDEP). The Fraser (conservative) government passed the Aboriginal Councils and Associations Act (henceforth ACA Act) in 1976, with Labor's support. The advocates and legislators of the ACA Act justified it as acknowledging overlooked Indigenous political capacity by giving it a formal vehicle; acknowledging cultural difference in Indigenous ways of associating; bringing order, transparency and accountability to Aboriginal peoples' collective action; and sparing Aboriginal people the burden of understanding the complexities of mainstream incorporation laws. The ACA Act was accepted and used by the Hawke and Keating governments. The Howard government had no quarrel with this legacy when it replaced the ACA in 2007 with the Corporations (Aboriginal and Torres Strait Islander) Act (henceforth CATSI Act). Both Acts have authorised the Office of the Registrar of Aboriginal/Indigenous Corporations to examine the conduct of registered corporations, but the CATSI Act is notable for declaring that the office's purposes are not only disciplinary but also tutelary.

Indigenous Australians have sometimes felt that their customary ways of doing business were under pressure from these Acts' oversight. ${ }^{47}$ When ATSIC was asked by the Keating government in 1994 to comment on proposed amendments to the ACA Act that would strengthen the Registrar of Aboriginal Corporations, the commissioners persuaded the minister to defer changes, pending a review of the ACA Act to be

46 Tim Rowse, 'The Indigenous Sector', in Culture, Economy and Governance in Aboriginal Australia: Proceedings of a Workshop of the Academy of Social Sciences, ed. Diane Austin-Broos and Gaynor Macdonald (Sydney: Sydney University Press, 2005), 207-24.

47 For an Indigenous scholar's critique, see Terry Widders, 'On the Dreaming Track to Citizenship: Indigenous People and the Ambivalence of Citizenship', in Martung Upah: Black and White Australians Seeking Partnership, ed. Anne Pattel-Gray (Blackburn: HarperCollins, 1996), 212-29. 
conducted by ATSIC. The review was conducted by Dr James Fingleton for the Australian Institute of Aboriginal and Torres Strait Islander Studies. While the Fingleton review was in process, the Howard government's March 1996 election brought to power MPs still sceptical about the delegation of government program spending to Indigenous corporations. When the registrar annually reported the exercise of his powers, he always brought to light some instances of dishonesty and/or incompetence that reinforced the conviction that government oversight, tuition and, occasionally, discipline were needed by Indigenous Australians who engaged in formal collective action. Submissions to the Fingleton review cautioned against presuming that all Indigenous custom was a problem to be solved by firmer adherence to non-Aboriginal norms. Fingleton recommended a relaxation of restrictions on the design of Indigenous corporations, so that they could align better with Indigenous custom; he sought to reconcile the ways of organised Indigenous Australians with the wider society's norms of good governance. Without abjuring the principle that legislation should keep Indigenous corporations accountable to members, clients and governments, his recommendations acknowledged the risk that imposed practices of governance could alienate Indigenous Australian members, clients and staff, eroding their confidence that the corporations really belonged to them and were responsive to them.

The Howard government did not change the ACA Act in response to Fingleton's review. Meanwhile, the registrar continued to seek amendments to further empower oversight and corrective intervention. The registrar noted two significant changes in the ACA Act's environment in the 1990s. One was that a High Court ruling had obliged Australian lawmakers to reconstruct all corporate regulation, resulting in the Corporations Act 2001. The other change was that the implementation of the Native Title Act was giving rise to many Prescribed Bodies Corporate, as title-holding entities. In November 2000, the registrar commissioned a review of the ACA Act by a multidisciplinary team headed by lawyers Corrs Chambers Westgarth. The review's consultation paper asked whether a specific Indigenous incorporation statute was still necessary, and (if so) whether it should be for all Indigenous corporations, regardless of size. Consultations found widespread support for such a statute with no restriction on size. As well, according to the registrar, supporters wanted the Act to be both 'more flexible' about the design of corporations and more consistent with the Corporations Act, while enabling the registrar's office to focus more on 'capacity building and assistance'. 
According to the 'Final Report and Recommendations' of the Corrs review (released in December 2002), the rationale for continuing an Indigenousspecific incorporation statute was that most Indigenous corporations had social rather than commercial objectives. The review sought to recognise greater diversity among those social purposes: it acknowledged that there could be different constitutions and reporting requirements, and it recommended that the registrar have discretion to modify the latter. Meanwhile, the responsibilities of directors and officers could more closely align with the Corporations Act.

The Howard government acted on the Corrs review, with a Bill that largely followed its recommendations. The intent of the CATSI Act is to be 'a special measure to advance and protect the interests of Aboriginal and Torres Strait Islander people and their respective cultures' ${ }^{48}$ Labor voted for the Bill, though warning that regulation must strike a delicate balance between securing good governance and allowing Indigenous clients and members to feel that their corporations belonged to them. ${ }^{49}$ The CATSI Act is further evidence that Indigenous public policy is bipartisan in its aspiration to recognise a distinct Indigenous institutional order in order to develop certain capacities within it.

\section{The Howard Government and ATSIC}

Although John Howard and his Coalition colleagues had vigorously opposed the legislation of ATSIC in 1989, the Howard government waited until it was almost at the end of its third term before announcing that it would abolish ATSIC, and it did not make that decision until after the Labor Party, in Opposition, announced that it had lost confidence in ATSIC. To explain the demise of ATSIC we need to understand how it lost the support of both the Coalition and Labor.

Affording ATSIC greater autonomy, the Howard government in 1999 enabled that the chair of ATSIC be elected by the Board of Commissioners. In December 1999, the board elected Geoff Clark. Howard and Clark

48 Corporations (Aboriginal and Torres Strait Islander) Bill 2005, Parliamentary Library BILLS DIGEST (Information analysis and advice for the Parliament), 31 January 2006, 82.

49 See House of Representatives Hansard 11 October 2006 for the debate on a package of Bills: the Corporations Amendment (Aboriginal and Torres Strait Islander Corporations) Bill 2006; the Corporations (Aboriginal and Torres Strait Islander) Consequential, Transitional and Other Measures Bill 2006 (the transitional Bill); and the Corporations (Aboriginal and Torres Strait Islander) Bill 2005 (the amendment Bill). 
were opposed in their views about the place of Indigenous rights in 'reconciliation'. The appeal of 'practical reconciliation' was Howard's most potent counter to Clark's and ATSIC's insistence that Indigenous Australians be empowered to enact their distinct rights, including the right to negotiate a treaty. While they agreed that 'reconciliation' included reducing Indigenous Australians' socioeconomic 'disadvantage', ATSIC under Clark argued that the key to overcoming disadvantage was greater government recognition of Indigenous Australians' right of self-determination as distinct peoples within the Australian nation. One occasion for Clark to assert the 'rights' approach was Corroboree 2000, on Saturday 27 May, at the Sydney Opera House. There the Council for Aboriginal Reconciliation presented the Australian Declaration towards Reconciliation, proposing legislation that would commit the Australian Government to negotiate a comprehensive agreement with Indigenous Australians. Howard's speech at Corroboree 2000 deflected this idea with emollient words:

Reconciliation will mean different things to different people. There is a spiritual component to reconciliation just as there is a practical component to it. And you cannot achieve reconciliation without acknowledging as I do and the Government I lead does, the self-evident fact that the indigenous people of Australia are the most profoundly disadvantaged within our communities. And part of the process of reconciliation is to adopt practical measures to address that disadvantage. ${ }^{50}$

This was typical of the Howard government's dismissal of an approach to reconciliation that accorded importance to distinct Indigenous rights. ${ }^{51}$

The reputations of Clark and his deputy chair Ray Robinson soon diminished for reasons that had nothing to do with Howard's rhetorical deflection of 'rights'. In July 2002 police in Victoria decided not to prosecute Clark for rape, after 12 months of investigating well-publicised accusations. He was also being prosecuted for 'riotous behaviour' after a fight in a hotel. Some observers questioned the political judgement of

50 John Howard, 'Corroboree 2000 Speech', AustralianPolitics.com, accessed 14 January 2020, australianpolitics.com/2000/05/27/john-howard-address-to-corroboree-2000.html\#more-10691.

51 For critical accounts of Howard's selective rejection of the Council for Aboriginal Reconciliation's 'Australian Declaration Towards Reconciliation' at Corroboree 2000, see Gunstone, 'The Impact', 63-64, and Robbins, 'The Howard Government', 321-22. For Clark's response to this event, reiterating the demand for a treaty, see Geoff Clark, 'Not Much Progress', in Reconciliation: Essays on Australian Reconciliation, ed. Michelle Grattan (Melbourne: Black Inc., 2000), 228-34. 
ATSIC's Board of Commissioners in covering the costs of his defence by a top Melbourne QC. In Queensland, ATSIC Commissioner Ray Robinson began legal proceedings against the Courier Mail for alleging his improper financial dealing, while ATSIC's own internal Office of Evaluation and Audit investigated the claim. ${ }^{52}$

Without referring to these problems of individual reputation, Minister for Indigenous Affairs Philip Ruddock announced in June 2002 that ATSIC would be reviewed. Ruddock presented the inquiry as his response to Indigenous disquiet. In July 2002 even Clark acknowledged that some Indigenous Australians were so alienated from ATSIC that they might not participate in ATSIC's fourth election (scheduled to be held on 19 October 2002). Voter registration, he acknowledged, was a test of ATSIC's significance to Indigenous Australians. ${ }^{53}$ The October election produced a new board and, in December 2002, Clark and Robinson were successful in persuading commissioners that they should continue as chair and deputy chair.

Meanwhile, criticism of ATSIC continued, from Indigenous people whom the minister could not ignore. Patrick Dodson was reported as calling for ATSIC to be phased out; ATSIC was tarnished, he reportedly said, by the actions of its leaders. ${ }^{54}$ At the same time, newspapers reported a court case in which Clark's predecessor as chair, Gatjil Djerrkura, was accused of sexual harassment. Commissioner Jenny Pryor was quoted as saying that a woman should lead ATSIC, given the behaviour of its male leaders. ${ }^{55}$ In November 2002, Ruddock announced rules that would allow him to remove a commissioner 'for a variety of behavioural offences, including causing public embarrassment to an Aboriginal organisation, seriously disrupting meetings and sexual harassment in or out of the workplace'. ${ }^{56}$ Lowitja O'Donoghue wrote to Ruddock asking him why he was not sacking Clark. ${ }^{57}$

52 Chris Graham, 'ATSIC Launches Inquiry; Robinson Claims Innocence', National Indigenous Times, 31 July 2002, 1, 4 .

53 Chris Graham, 'ATSIC Enters Election Mode', National Indigenous Times, 31 July 2002, 1, 17.

54 Chris Graham and AAP, 'Dodson Comments Sour Grapes: Sugar', National Indigenous Times,

23 October 2002, 1.

55 'Pryor Says ATSIC Needs a Woman at the Helm', National Indigenous Times, 23 October 2002, 10.

56 Chris Graham, 'Tough New Rules for ATSIC Board', National Indigenous Times, 20 November $2002,1,11$.

57 'ATSIC under Fire', National Indigenous Times, 30 April 2003, 4. 
On 12 November 2002 the minister announced the ATSIC inquiry's terms of reference and the panel that would conduct the review: Bob Collins, John Hannaford and Jackie Huggins. They delivered their report 12 months later, recommending a number of reforms to make ATSIC more accountable to Indigenous Australians. Explaining Indigenous Australians' estrangement as an effect of ATSIC's concentration of power at the national level, the panel sought more power for elected regional councils. The Opposition's response was to announce on 30 March 2004 that it would abolish ATSIC if it won the 2004 election and replace it with a directly elected national Indigenous body. This emboldened the Howard government to announce on 15 April 2004 that it would abolish ATSIC, and so it did in the final months of its third term.

Evidently, not all Indigenous voters were displeased by the government's action. In the absence of studies that constitute a sample of Indigenous Australians of voting age, it is possible to get an idea of changes in Indigenous party preference by examining returns from booths where the voters were almost entirely Aboriginal or Torres Strait Islander. At 37 such booths across 12 electorates, in the 2004 election, one-third (4,294 out of 12,919 voters) of voters chose Coalition candidates - a 'massive swing to the federal Coalition', according to the National Indigenous Times. ${ }^{58}$

\section{The Northern Territory Intervention}

The emergence of Indigenous critics of ATSIC was symptomatic of a growing diversity in public statements by prominent Indigenous Australians. Howard noted and welcomed the thawing of his relationship with Indigenous Australia. In his first term, he had made it difficult for Indigenous leaders to bond publicly with him when he was openly diminishing the property rights of native title holders, and for 10 years (1997-2007) he refused to apologise to the Stolen Generations (while expressing his 'very deep sorrow for indigenous people who suffered under the injustices of policies pursued by past generations'). ${ }^{59}$ When Howard saw signs that Indigenous leaders were moving closer to him, he pointed them out. In a speech to the House on 3 June 1999, he approvingly noted

58 Chris Graham, 'Wild Swings Amid Black Payback in Qld and SA', National Indigenous Times, 13 October 2004, 6. Graham also suggested that regional variations in the size of swing owed much to Indigenous voters' hostile responses to actions by state Labor governments.

59 Howard, CPD HoR, 27 May 1997, 4113. 
the critique of 'welfare dependency' voiced by Noel Pearson-'a person who has not always been complimentary about the policies of the government I lead'. ${ }^{60}$ On 26 August 1999, Howard thanked Senator Aden Ridgeway for helping to formulate a motion expressing:

Deep and sincere regret that Indigenous Australians suffered injustices under the practices of past generations, and for the hurt and trauma that many Indigenous people continue to feel as a consequence of those practices.

Howard mentioned Ridgeway warmly four times in his speech, representing Ridgeway's cooperation as symptomatic of Indigenous leaders starting to meet him 'halfway'. ${ }^{61}$ In the context of such a conciliatory moment, we can better understand the Howard government amending the ATSIC Act so that, from 1999, the chair of ATSIC was no longer appointed by the minister for Aboriginal affairs but elected by the other ATSIC commissioners. The commissioners chose Geoff Clark in 1999 and in 2002 to Chair ATSIC; this added to the diversity of Indigenous voices with an opportunity to address the public, as some prominent Indigenous figures did not agree with Clark. By the time he abolished ATSIC in 2004, Howard was confident that he could pick his own team of Indigenous advisers. Notwithstanding that around 200 Indigenous people gathered in Adelaide (11-14 June 2004) to call for a new elected national Indigenous representative body, the Howard government appointed a small, advisory National Indigenous Council (NIC), chaired by the Western Australian magistrate Sue Gordon, to advise the Ministerial Taskforce on Indigenous Affairs. The NIC's first meeting on 8-9 December 2004 set priorities for government action: early childhood intervention, safer communities and reducing 'passive welfare'. ${ }^{62}$

The currency of the latter term showed the take-up of Noel Pearson's critique of Indigenous Australians' acquired irresponsibility. Noel Pearson from 1999 onwards presented an historical thesis: that one unintended consequence of the Indigenous right to welfare was the collapse in the cohesion and moral strength of the Aboriginal family. The scandal surrounding Clark and Robinson in the period 2002-04 had helped

60 Howard, CPD HoR, 3 June 1999, 6017.

61 Howard, CPD HoR, 26 August 1999, 9205.

62 NIC members were Sue Gordon, Wesley Aird, Archie Barton, May Ann Bin-Sallik, Miriam Rose Baumann, Joseph Elu, Robert Lee, Adam Goodes, Sally Goold, John Moriarty, Warren Mundine, Joe Procter, Michael White and Tammy Williams. 
to dramatise the problem as a public crisis of Indigenous masculinity. Were the (apparent, alleged) failings of Indigenous communities a symptom of unresolved tensions between Indigenous men and women? From this Indigenous discourse about Indigenous society there emerged new and urgent figurations of Indigenous 'disadvantage': the battered woman, the neglected child. ${ }^{63}$ These stories of 'disadvantage' were more vivid than the statistics of Indigenous-non-Indigenous disparity, and they raised the question of who was responsible for defending women and children from further harm.

The Howard government's answer to that question was the Australian government. The opportunity to give that answer came in 2007 when the Northern Territory Government responded cautiously to a report, Little Children are Sacred, that represented children in remote Aboriginal communities as neglected and/or abused. The Howard government seized on this exposé of Indigenous vulnerability, announcing the NTER. This package, presented on 21 June 2007 by Minister for Families, Community Services and Indigenous Affairs Mal Brough, included the following items:

- alcohol restrictions on Northern Territory Aboriginal land

- controls on welfare recipients' expenditure

- linking welfare payments to parental performance in getting their children to school

- compulsory health checks for Aboriginal children

- acquiring certain townships on Aboriginal land, through five-year leases

- increasing police presence in certain communities

- new rent and tenancy arrangements for households

- additional funds for housing

- banning X-rated pornography in prescribed communities

- ending the permit system for defined areas within Aboriginal lands

- phasing out the CDEP scheme to encourage people into 'mainstream' employment

- appointing managers of all government business in certain communities.

63 This Indigenous public auto-critique began to emerge in the 1980s and grew in strength. See Sarah Maddison, Black Politics (Crows Nest: Allen and Unwin 2009), 185-205; Tim Rowse, Indigenous and other Australians since 1901 (Sydney: UNSW Press 2017), 406-13. 
That many of these measures were frankly paternalistic constituted what Howard, in Lazarus Rising, called a 'paradigm change'. They were politically possible not only because Howard's fourth term benefited from a conservative majority in the Senate, but also because Howard had, by then, secured some Aboriginal leader's public endorsement of his response to what was widely acknowledged as an 'emergency' in remote Indigenous communities. Of course, there were many Aboriginal and Torres Strait Islander critics of the NTER, as coverage by the National Indigenous Times and Koori Mail made clear, arguing that the NTER disempowered community leaders who had long been struggling against family violence. ${ }^{64}$ But the 'Taskforce' appointed by the Howard government to oversee the NTER was chaired by the Aboriginal magistrate Sue Gordon, who had also been foundation chair of the government-chosen NIC. Aboriginal politician Adam Giles, soon to contest unsuccessfully the Northern Territory seat of Lingiari as the Country Liberal Party candidate in the 2007 election, expressed his support for the NTER. ${ }^{65}$

\section{Conclusion}

Assessing whether the Northern Territory intervention was a 'paradigm change' depends partly on how we describe the policy orthodoxy from which, in Howard's view, it broke. In Lazarus Rising, Howard labels that orthodoxy as 'separate development, with a heavy overlay of guilt and shame'. This orthodoxy was supported by 'the old guard of the Aboriginal leadership, the ALP' and much of the press. ${ }^{66}$

I have argued that Howard's 2007 break from policy orthodoxy should not be described as his repudiation of 'separate development'. Whatever that poorly defined term might mean, it arguably includes acknowledging in legislation that Indigenous Australians have distinct rights to land and seas and a distinct suite of formal representative institutions. The Howard government, in practice, endorsed both: it fashioned a version of legislated native title that made native title acceptable to the Coalition, supported ATSIC until its Labor champions and many Indigenous

64 Muriel Bamblett, chairwoman of the Secretariat of National Aboriginal Child Care (SNAICC)), rehearsed the history of SNAICC's own fruitless lobbying of Labor and non-Labor governments in August 2007: 'Heartbreak Hill', National Indigenous Times, 23 August 2007, 16-18.

65 Interviewed by Graham Ring, 'Doing the "Right" Thing', National Indigenous Times, 26 July 2007, 33 .

66 Howard, Lazarus, 280. 
leaders had lost faith in it, and renewed the distinct regulatory regime that gives the Indigenous sector incentives to self-discipline. Further, although Howard congratulated himself for making an eleventh-hour break from 'separate development' by initiating the NTER in June 2007, it is relevant to point out that the succeeding Labor government did not repudiate the NTER, but largely embraced it in a 'bipartisan' commitment to actions that could be shown to attain 'the objectives which have been set' (in Kevin Rudd's words). ${ }^{67}$

Since the Whitlam government, there has been more continuity between Labor and Coalition governments in Indigenous affairs policies, though each side has an interest in playing down continuities and overstating philosophical differences. When each side of Australian politics has a chance to govern Indigenous affairs, it seeks distinct terms in which to cast its commitment to much the same set of statutes, institutions and programs. To flag the distinct worth of a government's approach, it helps if Indigenous Australians publicly endorse what the government is doing and echo the government's stated reasons for its actions. Therefore, a big part of governing Indigenous affairs is to establish conspicuous Indigenous allies. For Howard this was not easy, as a rhetorically skilful Keating had clothed himself in the new national narrative (the Redfern speech of December 1992), demonstrated empathy with rights-talking Indigenous leaders and legislated a 'right' of native title. Howard's difficulties in portraying himself as a friend of Indigenous Australia are evident in the resentful expressions I have quoted from Howard's first term, phrases recycled in Lazarus Rising. In his refusal to apologise to the Stolen Generations from 1997 to 2007, Howard was prepared to distance himself emotionally from many Indigenous Australians, as long as this stance assured his distinction, as well, from the 'abject' and 'guilty' nonIndigenous Australians who aligned with Labor.

The terms in which a leader can present him/herself credibly as a champion of Indigenous Australia have changed from decade to decade. The High Court's Mabo judgment gave the government of the day no choice but to make the customary Indigenous right to land and sea the defining issue

67 As quoted by Will Sanders, 'Ideology, Evidence and Competing Principles in Australian Indigenous Affairs: From Brough to Rudd via Pearson and the NTER', Australian Journal of Social Issues 45 (2010): 312-13, doi.org/10.1002/j.1839-4655.2010.tb00182.x. The promotion of Rudd's parliamentary apology to the Stolen Generations (February 2008) as if it defined his leadership has obscured the substantial continuity between the Howard and Rudd governments' Indigenous affairs policies. 
of a just relationship. It was Howard's fate to do what he could with the rights-based policy that eventuated. Not without difficulty, he persuaded his side of politics that it was best to embrace a modified version of the native title package, while seeking to shift the public's attention to as yet unmet Indigenous needs and away from perpetually distinct rights. His tireless rhetorical mission ('practical', 'compassion') met with more and more success largely because there was an emerging Indigenous constituency ready to endorse his terms as their own deeply felt concern. It helped Howard that some of those insisting on a 'rights' approach seemed, for a few years, conspicuously irresponsible in personal and financial matters. The morally charged focus on 'responsibility' dramatised a distinction within Indigenous Australia between the flourishing and the vulnerable - a gap with roots in Indigenous ways of reckoning with each other.

The 'paradigm shift' that Howard celebrates in Lazarus Rising must be understood not only in terms of its program innovations (such as the imposed 'Basics Card') but also in terms of its novel political alliances: the actions justified by Howard as an expression of 'compassion' towards the most vulnerable Indigenous people were now publicly endorsed by one side of an increasingly divided Indigenous constituency. To understand the politics of the NTER we need to consider not only the overstated competing party ideologies but also the under-analysed diversity that has emerged in Indigenous understandings of 'social justice' and 'responsibility'. 
This text is taken from ANU Historical Journal II: Number 2, published 2020 by ANU Press, The Australian National University, Canberra, Australia.

doi.org/10.22459/ANUHJII.2020.09 